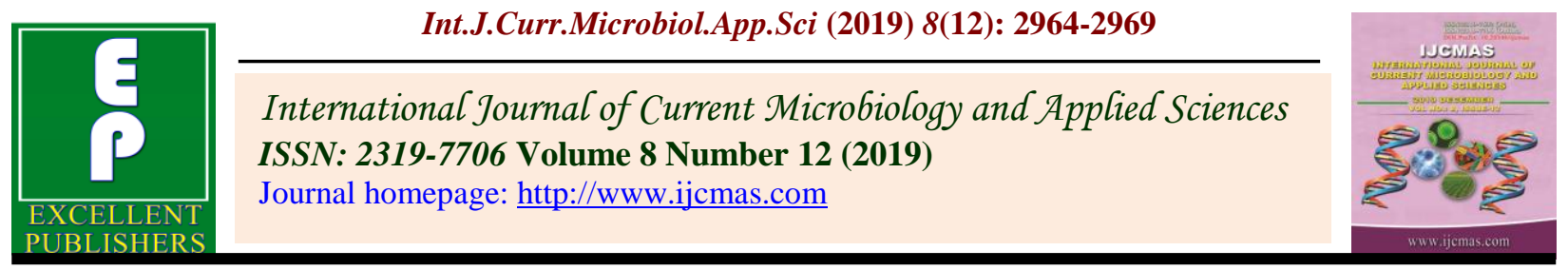

Original Research Article

https://doi.org/10.20546/ijcmas.2019.812.344

\title{
Professional Competence of Agricultural Technology Management Agency (ATMA) Personnel
}

\author{
K. G. Khadayata ${ }^{1 *}$, S. R. Patel ${ }^{2}$ and Alkesh R. Patel ${ }^{3}$ \\ ${ }^{1}$ Sardar Patel Agricultural \& Educational Museum, DoEE, Anand Agriculture University, \\ Anand, Gujarat-388110, India \\ ${ }^{2}$ College of Agriculture, AAU, Jabugam, Gujarat-391 155, India \\ ${ }^{3}$ Department of Agril. Extension \& communication management, B.A.C. A, AAU, Anand, \\ Gujarat, India
}

*Corresponding author

\section{A B S T R A C T}

Keywords

ATMA Personnel,

competence,

Agricultural,

components

Article Info

Accepted:

25 November 2019

Available Online:

10 December 2019
Human resources form the bedrock of the agricultural extension system. The agricultural sector requires skilled human resources who are capable of all aspects of work in agricultural and rural centres, including producing, processing and marketing of agricultural products. The present study was carried out in middle Gujarat region and ATMA personnel (Agricultural Technology Management Agency) selected as respondents. The ex-post facto research design was used for the study and personal interview schedule used for the data collection. Majority of the ATMA personnel were observed at high or medium to a high level on different components of professional competence. The great majority (93.58 per cent) of the ATMA personnel were found in the category of high to very high level of professional competence.

\section{Introduction}

In today's highly competitive workforce environment, competencies of workers are a key element in shaping organization development. Competencies have proven to be a tool to improve organizational performance by focusing on individual performance. Boyatzis (1982) defines competency as "an underlying characteristic of a person which results in effective and superior performance in a job". A competency is an individual characteristic that can be measured or counted reliably and that can be shown to differentiate significantly excellent and average performers, or between efficient and ineffective performers. Meanwhile, competency can be described as a set of behaviour patterns that an incumbent needs to bring to a position to perform its tasks and functions in the delivery of desired results or outcomes (Bartram, et. al, 2002; Woodruffe, 
1992). Registered society responsible for technology dissemination at the district level. As a society, it would be able to receive and expend project funds, entering into contracts $\&$ agreements and maintaining revolving accounts that can be used to collect fees and thereby recovering the operating cost. The Agricultural Technology Management Agency or "ATMA" model was viewed as the central institutional innovation that would address the problems of the extension system. In every organization, people have different roles geared towards the fulfilment of organizational goals. It is thus essential to help every individual to know and understand the part he/she is to play in the whole arrangement. Such individuals must also possess the professional competency that will enable them to carry out such roles effectively and efficiently. The extension personnel of ATMA, as like other organizations, should have the professional competency to effectively carry out their roles. (http://www.agriinfo.in).

Professional Competence indicates sufficiency of knowledge and skill that a person needs to act in a wide variety of situations. The ATMA can be regarded as responsible for all the technology dissemination activities at the district level in the state. ATMA personnel, being responsible for agricultural technology dissemination, work in the linkage with all the line departments, research organization, NGO's and other agencies associated with agricultural development in the district. They also communicate with farmers. In this context, the competence level of ATMA personnel would be crucial for effective technology dissemination. Hence, it was thought worthwhile to study the professional competence of ATMA personnel. It is also important to find out which of the characteristics of ATMA personnel are significantly responsible for moulding their professional competence.
The main objectives of this study includes, to study the Professional competence of ATMA personal

\section{Materials and Methods}

The present investigation was carried out in all the nine districts of middle Gujarat region on ATMA Personnel of middle Gujarat region. The Agricultural Technology Management Agency (ATMA) is an autonomous organization responsible for technology dissemination activities at the district level which has different categories of personnel at different levels. Ex-post-facto research design (kerliger 1976) was used. Personal interview schedule was used for data collection. Professional competence includes the capability to perform the duties of one's profession or to perform the particular professional task with the skill of acceptable quality.

An attempt was made in the present investigation to develop an instrument to measure professional competence. In order to develop a device for measuring the overall professional competence, it was necessary to identify the factors/components.

\section{Computation of overall Professional Competence Index}

Professional competence index of the respondents was determined by using the following formula.

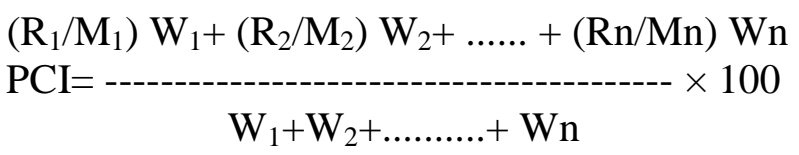

Where,

PCI $=$ Overall Professional Competence Index of the ATMA personnel

$\mathrm{R}_{1}, \mathrm{R}_{2} \ldots . . . \mathrm{R}_{\mathrm{n}}=$ professional competence Score 
obtained by ATMA personnel for Particular professional competence component

(Received score for each Indicator by each ATMA personnel)

$\mathrm{M}_{1}, \mathrm{M}_{2} \ldots . . \mathrm{M}_{\mathrm{n}}=$ Potential score of the ATMA personnel for particular professional Competence Indicator (Maximum score one can get for each component)

$\mathrm{W}_{1}, \mathrm{~W}_{2} \ldots . . . \mathrm{W}_{\mathrm{n}}=$ Weightage score of the particular professional Competence component

\section{Results and Discussion}

\section{Human relation skill}

The majority (87.23 per cent) of the ATMA personnel had medium to a high level of human relation skill while remaining of 09.17 and 03.60 per cent of them were found with a very high and low level of human relation skill, respectively.

\section{Leadership skill}

The great majority (92.66 per cent) of the ATMA personnel had medium to a high level of human relation skill and only 07.34 per cent of them were observed with a very high level of leadership skill.

\section{Technical expertise}

The majority (72.46 per cent) of the ATMA personnel were found with medium to a high level of technical expertise while 19.26 per cent of them had a low level of technical expertise in their job.

Only 8.28 per cent of ATMA personnel were observed with a very high level of technical expertise.

\section{Planning skill}

The majority (87.16 per cent) of the ATMA personnel had high to medium level of planning skill, followed by 12.84 percent of them with a very high level of planning skill.

\section{Organizing skill}

Slightly higher than half (55.04 per cent) of the ATMA personnel were found with high organizing skill, while 33.02 and 11.94 per cent of the ATMA personnel had medium and very high organizing skill, respectively.

\section{Communication skill}

Majority (88.06 per cent) of the ATMA personnel had high to very high level of communication skill, whereas 11.94 percent of them were found with medium level of communication skill in their job.

\section{Coordination skill}

Majority (85.33 per cent) of the ATMA personnel were observed with medium to high level of coordination skill, while 10.09 per cent of them had very high level of coordination skill.

\section{Supervision skill}

Majority (82.57 per cent) of the ATMA personnel were found in high to medium category of supervision skill, followed by 17.43 per cent of them who were found with very high level of supervision skill.

\section{Conflict management skill}

Slightly higher than three-fifth (61.46 per cent) of the ATMA personnel had medium level conflict management skill, while 26.60 per cent and of 11.94 per cent of them were found with high and very high level of conflict management skill, respectively. 
Table.1 Component wise professional competence of ATMA Personnel

\begin{tabular}{|c|c|c|c|}
\hline \multicolumn{4}{|c|}{ Human relation Skill } \\
\hline Sr. No. & Category & Frequency & Per cent \\
\hline 1 & Very low (05 to 08 score) & 00 & 00.00 \\
\hline 2 & Low (09 to 12 score) & 04 & 03.60 \\
\hline 3 & Medium (13 to 17 score) & 71 & 65.13 \\
\hline 4 & High (18 to 21 score) & 24 & 22.10 \\
\hline 5 & Very high ( 22 to 25 score) & 10 & 09.17 \\
\hline & Total & 109 & 100.00 \\
\hline \multicolumn{4}{|c|}{ 2. Leadership skill } \\
\hline 1 & Very low (08 to 13 score) & 00 & 00.00 \\
\hline 2 & Low (14 to 20 score) & 00 & 00.00 \\
\hline 3 & Medium (21 to 27 score) & 66 & 60.55 \\
\hline 4 & High (28 to 34 score) & 35 & 32.11 \\
\hline 5 & Very high ( 35 to 40 score) & 08 & 07.34 \\
\hline \multicolumn{2}{|r|}{ Total } & 109 & 100.00 \\
\hline \multicolumn{4}{|c|}{ 3. Technical expertise } \\
\hline 1 & Very low (05 to 08 score) & 00 & 00.00 \\
\hline 2 & Low (09 to 12 score) & 21 & 19.26 \\
\hline 3 & Medium (13 to 17 score) & 55 & 50.45 \\
\hline 4 & High (18 to 21 score) & 24 & 22.01 \\
\hline 5 & Very high ( 22 to 25 score) & 09 & 08.28 \\
\hline \multicolumn{2}{|r|}{ Total } & 109 & 100.00 \\
\hline \multicolumn{4}{|c|}{ 4. Planning skill } \\
\hline 1 & Very low (06 to 10 score) & 00 & 00.00 \\
\hline 2 & Low (11 to 15 score) & 00 & 00.00 \\
\hline 3 & Medium (16 to 20 score) & 25 & 22.94 \\
\hline 4 & High ( 21 to 25 score) & 70 & 64.22 \\
\hline 5 & Very high (26 to 30 score) & 14 & 12.84 \\
\hline \multicolumn{2}{|r|}{ Total } & 109 & 100.00 \\
\hline \multicolumn{4}{|c|}{ 5. Organizing skill } \\
\hline 1 & Very low (07 to 12 score) & 00 & 00.00 \\
\hline 2 & Low (13 to 18 score) & 00 & 00.00 \\
\hline 3 & Medium (19 to 23 score) & 36 & 33.02 \\
\hline 4 & High (24 to 29 score) & 60 & 55.04 \\
\hline 5 & Very high (30 to 35 score) & 13 & 11.94 \\
\hline \multicolumn{2}{|r|}{ Total } & 109 & 100.00 \\
\hline \multicolumn{4}{|c|}{ Communicational skill } \\
\hline 1 & Very low (06 to 10score) & 00 & 00.00 \\
\hline 2 & Low (11 to 15 score) & 00 & 00.00 \\
\hline
\end{tabular}




\begin{tabular}{|c|c|c|c|}
\hline 3 & Medium (16 to 20 score) & 13 & 11.94 \\
\hline 4 & High (21 to 25 score) & 65 & 59.63 \\
\hline \multirow[t]{2}{*}{5} & Very high ( 26 to 30 score) & 31 & 28.43 \\
\hline & Total & 109 & 100.00 \\
\hline \multicolumn{4}{|c|}{ Coordination skill } \\
\hline 1 & Very low (03 to 04 score) & 00 & 00.00 \\
\hline 2 & Low (05 to 07 score) & 05 & 04.58 \\
\hline 3 & Medium (08 to 10 score) & 68 & 62.38 \\
\hline 4 & High (11 to 13 score) & 25 & 22.95 \\
\hline \multirow[t]{2}{*}{5} & Very high (14 to 15 score) & 11 & 10.09 \\
\hline & Total & 109 & 100.00 \\
\hline \multicolumn{4}{|c|}{ Supervision skill } \\
\hline 1 & Very low (06 to 10score) & 00 & 00.00 \\
\hline 2 & Low (11 to 15 score) & 00 & 00.00 \\
\hline 3 & Medium (16 to 20 score) & 32 & 29.35 \\
\hline 4 & High (21 to 25 score) & 58 & 53.22 \\
\hline \multirow[t]{2}{*}{5} & Very high (26 to 30 score) & 19 & 17.43 \\
\hline & Total & 109 & 100.00 \\
\hline \multicolumn{4}{|c|}{ Conflict management skill } \\
\hline 1 & Very low (04 to 07 score) & 00 & 00.00 \\
\hline 2 & Low (08 to 10 score) & 00 & 00.00 \\
\hline 3 & Medium (11 to 13 score) & 67 & 61.46 \\
\hline 4 & High (14 to 16 score) & 29 & 26.60 \\
\hline 5 & Very high (17 to 20 score) & 13 & 11.94 \\
\hline \multicolumn{2}{|r|}{ Total } & 109 & 100.00 \\
\hline \multicolumn{4}{|c|}{ 10. Motivational skill } \\
\hline $\mathbf{1}$ & Very low (05 to 08score) & 00 & 00.00 \\
\hline 2 & Low (09 to 12 score) & 00 & 00.00 \\
\hline 3 & Medium (13 to 17 score) & 12 & 11.00 \\
\hline 4 & High (18 to 21 score) & 22 & 20.18 \\
\hline 5 & Very high ( 22 to 25 score) & 75 & 68.82 \\
\hline \multicolumn{2}{|r|}{ Total } & 109 & 100.00 \\
\hline
\end{tabular}

Table.2 ATMA personnel according to their overall professional competencen $=109$

\begin{tabular}{|c|l|c|c|}
\hline Sr. No. & \multicolumn{1}{|c|}{ Category } & Frequency & Per cent \\
\hline $\mathbf{1}$ & Very low (00to 20score) & 00 & 00.00 \\
\hline $\mathbf{2}$ & Low (21 to 40 score) & 00 & 00.00 \\
\hline $\mathbf{3}$ & Medium $(41$ to 60 score) & 07 & 06.42 \\
\hline $\mathbf{4}$ & High $(61$ to 80 score $)$ & 82 & 75.24 \\
\hline $\mathbf{5}$ & Very high $(81$ to 100 score $)$ & 20 & 18.34 \\
\hline & $\quad$ Total & $\mathbf{1 0 9}$ & $\mathbf{1 0 0 . 0 0}$ \\
\hline
\end{tabular}




\section{Motivational skill}

Majority (89.00 per cent) of the ATMA personnel had very high to high level of motivational skill, followed by 11.00 per cent of them with medium level of motivational skill.

\section{Overall professional competence of ATMA personnel}

Professional competence includes capability to perform the duties of one's profession or to perform particular professional task with the skill of acceptable quality.

In the present study, an attempt was made to measure the professional competence of ATMA personnel on different components as discussed above. Further, on the basis of data on different components, overall professional competence index was calculated for each respondent with the help of formula as stated in the methodology chapter and based on their PCI score; they were grouped arbitrarily into five categories as shown in Table 2.

It is evident from the Table 2 that almost three fourth (75.24 per cent) of the ATMA personnel had a high level of overall professional competence, followed by 18.34 per cent and 06.42 per cent of them with very high level and a medium level of overall professional competence, respectively. None of the ATMA personnel was found in the category of the low and very low level of overall professional competence.
Human assets are one of the most significant resources available to any organization and employee competence and commitment largely determine the objectives that an organization can set for itself and to its success in achieving them. It can be concluded as majority of the ATMA personnel were observed at medium to high level on different components of professional competence. Majority of the ATMA personnel were found in the category of high to very high level of professional competence.

\section{References}

Bartram, D., Robertson, I. T., \& Callinan, M. (2002). Introduction: A Framework for Examining Organizational Effectiveness. In I.T. Robertson, M. Callinan, \& D. Bartram (Eds.), Organizational Effectiveness: The Role of Psychology (p. 1-12). Chichester, UK: Wiley.

Boyatzis, R. (1982). The Competent Manager: A Model for Effective Performance. New York: John Wiley \& Sons.

http://www.agriinfo.in

Kerlinger, F.N. (1976). Foundations of behavioural research. Surjeet

Publications, New Delhi, pp 198-204.

Woodruffe, C. (1992). What is meant by Competency? In: Sparrow, P.R., Boam, R., Eds. Designing and Achieving Competency. McGraw-Hill International.UK.

\section{How to cite this article:}

Khadayata K. G., S. R. Patel and Alkesh R. Patel. 2019. Professional Competence of Agricultural Technology Management Agency (ATMA) Personnel. Int.J.Curr.Microbiol.App.Sci. 8(12): 2964-2969. doi: https://doi.org/10.20546/ijcmas.2019.812.344 